\title{
TESES
}

\section{Sindicatos das trabalhadoras domésticas no Brasil: teorias da descolonização e saberes subalternos}

Joaze Bernardino Costa

Curso: Doutorado em Sociologia

Data da defesa: 15 de março de 2007

Orientadora: $\operatorname{Prof}^{\mathrm{a}} \mathrm{Dr}^{\mathrm{a}}$ Christiane Girard Ferreira Nunes

\section{Resumo}

A tese analisa a narrativa produzida pelos sindicatos das trabalhadoras domésticas no Brasil. Para tanto, realizamos entrevistas com integrantes dos principais sindicatos do país e pesquisa documental, onde procuramos recuperar a história dos congressos nacionais da categoria.

Ao focalizar a análise nos sindicatos, nosso objetivo foi entender como os atores que foram e são silenciados e ignorados pela narrativa hegemônica da nação - estruturada pelo mito da democracia racial e pelo mito do "bom senhor" ou "boa senhora" - percebem as relações sociais, especialmente as relações raciais. De acordo com as contribuições das teorias da descolonização (principalmente Dussel, Quijano e Mignolo), partimos do pressuposto de que o conhecimento não é produzido de uma posição neutra e universal, senão de diferentes posicionamentos dos atores num padrão hierárquico de poder, que nomeamos de colonialidade do 
poder. Assim, propomo-nos a escutar a enunciação das trabalhadoras domésticas sindicalizadas como uma enunciação subalterna.

Concluímos que o ativismo político das trabalhadoras domésticas produz um saber que articula classe, raça e gênero, que nos permite problematizar a narrativa hegemônica da nação, desestabilizando os seus significados culturais hegemônicos, estruturados pelo mito da democracia racial e do "bom senhor" ou "boa senhora".

Palavras-chave: trabalhadora doméstica, sindicato, raça, gênero, classe, teorias da descolonização, saberes subalternos.

\title{
O que o Congresso Nacional brasileiro pensa sobre a criminalidade
}

\author{
Laura Frade Rodrigues
}

Curso: Doutorado em Sociologia

Data da defesa: 30 de março de 2007

Orientador: Prof. Dr. Pedro Demo

\section{Resumo}

Representações do Legislativo Federal brasileiro sobre a criminalidade. $\mathrm{O}$ objetivo do trabalho foi explicitar o que o Congresso Nacional pensa a respeito do tema. O período sob análise foi a Qüinquagésima Segunda Legislatura (2003/2007) que, ao longo da história do Parlamento brasileiro registrou o 